\title{
eureka Featuring Torah Kachur
}

Dr. Torah Kachur is a passionate science communicator, as a science columnist for CBC Radio and co-creator of scienceinseconds.com, and a lecturer at the University of Alberta and MacEwan University.

Can you tell us a little bit about yourself as an undergraduate student? Would you have predicted that you'd be doing what you do now?

\section{9}

No, but I really didn't have any idea what I wanted to do. I graduated from $\mathrm{U}$ of $\mathrm{A}$ in honors molecular biology and genetics. It was kind of a funny story how I ended up there because I was your typical undergrad where after my first semester first year - I was actually at MacEwan because back in the day there was a university transfer program, and I was playing basketball for MacEwan.

I sort of put basketball aside and I didn't know what I wanted to do. I just knew I wanted to do science. So, when I was going into second year, I filled out the transfer form at the U of A admin office, and it was like, "Put your major and your minor down." I hadn't really thought about it and then I was like, okay, well, what are my favorite subjects? Obviously, biology - I've always been biominded. I put in microbiology as my major, and genetics as my minor. And then I got my acceptance letter, and the letter said genetics major and microbiology minor. They'd swapped them. So, I called the admin office and they're like, "Yeah, we made an administrative error, it's going to be $\$ 40$ if you want to change your major." So, I was like, oh, Iguess I'm in genetics. And that's how I got into my field.

\section{"Ikind of accidentally fell into all the various now-strengths of mine...it was all definitely by accident.”}

Many things happened to me in undergrad that were so ridiculous that kind of ended up placing me where I am. One of the things that happened after second year is that back in the day - I'm dating myself a bit - when you signed up for physiology and biochemistry, you couldn't do it on Beartracks. You had to go into their office and sign a form to enroll. So, I'm sitting there in the Biochem office and registering for the next semester and she just kind of offhandedly says, "Hey, do you want me to print off your schedule of your courses?" I'm like, "Yeah sure, that's nice, thank you." I get this printout - this is end of September of second year, a quarter of the way through the semester - and I see that I have been enrolled in Physiology 210 for a month. Nobody told me that actually they enrolled me in this 6-credit course, of which I'd missed a month, and I'm already in five classes and three labs, and then I added a sixth class because it was already past the drop deadline. So, I went to the office, and I was like, "You guys enrolled me?" and they're like, “Oh, yeah. Looks like no one ever called you." I'm like, "Yeah, can I drop then?” "No, sorry, it's past the add-drop deadline, you'll have to take a 50\% refund and a W". So, all of a sudden, I was taking six classes and three labs in second semester.

I did okay because I kind of figured out what this whole university business was about. So, I kind of accidentally fell into all the various now strengths of mine, which was kind of funny, and then I decided to finish an honors project to get my honors degree in genetics. So, it was all definitely by accident.

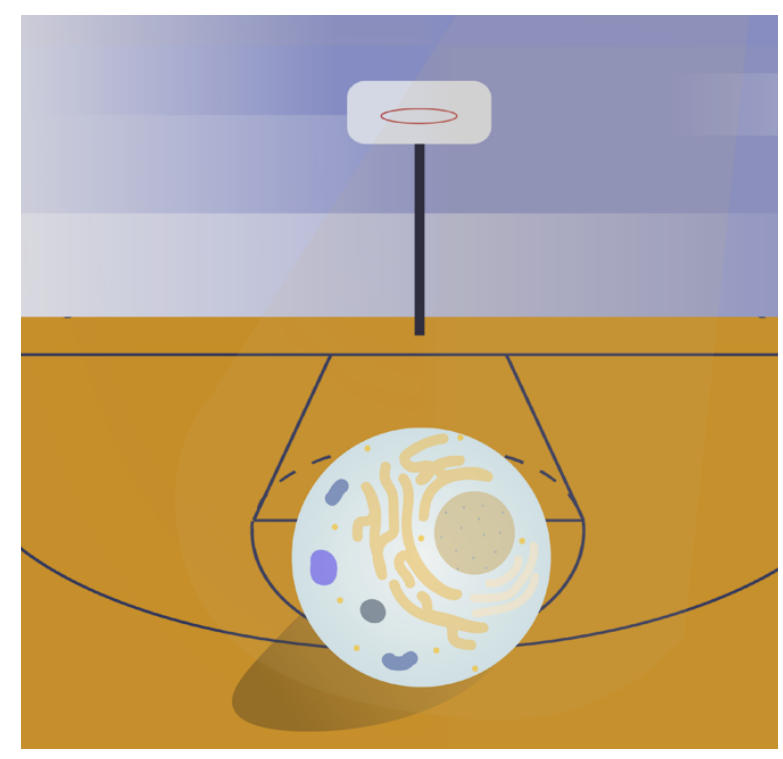

What did you do after undergrad?

I finished my undergrad and then decided to just go off and go traveling for the summer. When I came home, I didn't really even know how to look for jobs in science. So, 
I went back to one of my undergrad profs and set up a meeting and said, "Well, what's going on? Can you help me, mentor me a little bit?" And he said, "Why don't you come to grad school?” At that time, I'd already decided I was going to continue traveling, at least for some larger chunk of time. So I was talking to my future supervisor - Dave Pilgrim - and I said, "I don't really know what to do, I really like science and blah blah but I'm still not ready - I want kind of a little job, like a tech job, so I just make enough money to go traveling”. He's like, "Will you come to grad school?" And it's like "No, I'm going away. I want to go away away." He's like "You can do both". And I'm like "I mean, I want to go for four months at least - away". He's like, "Yeah, that's no problem. I'll just take you off payroll for those four months". So, then I was like, this is a great opportunity for me to balance what I want to do - travel - and what I want to do - which is grad school. So, I picked my grad school lab because of that opportunity, which was awesome.

I had worked with flies in my undergraduate honors project, and I really knew I really didn't want to work with flies, and I really liked the worm model system that we covered in my previous developmental genetics classes, and Dave Pilgrim worked in worms. So, I was like, okay well I want to work in worms, he's giving me this great opportunity to travel and balance going to grad school, and one of the major motivations was I get to wear sweatpants every day for the foreseeable future. I thought that was a great combination, so I decided to go into grad school. I think from an undergraduate audience, everyone who's an undergrad assumes that people who go and get higher level degrees - jobs that they're proud of - were super laser focused on what they wanted to do, and so much of me was just bumbling around and eventually landing on something that I enjoy.

I remember that same experience - there was a real defining moment for me where I realized, oh, you don't have to be a genius to be a scientist. They teach you how to do it. That wasn't until the last term of my degree that I realized this was an option and it's actually what I want.

Did you find that the academic pressure to publish was any different for you, knowing that you had other goals you wanted to accomplish?
I didn't feel the pressure to publish partly because I published in my first year. I got lucky in that I took on a project, which I asked to do - unbeknownst to me, [it] was a largely complete story from a previous graduate student and they needed a rework. We

needed a more in-depth set of experiments. So I came into a really good background of a project, and then was able to put the final touches on it. My experiments ended up being the linchpin, it wasn't something like repeating a western and then it was done. There was all this background, hypotheses, and we didn't know what it meant. My set of first real experiments were like, this is what it means, it's a really big deal, so that was really lucky as I published right away. I think I was in my first year and a half by the time it was actually out. That probably took a lot of pressure off, and because I did a rework of the whole paper, I ended up with first author even though I hadn't done most of the physical experiments. I basically started and rewrote the whole thing, so that was good. But we didn't have a lab that had publishing pressure. It was really 'Just do good work and we'll find a place to publish it'.

My first one was Journal of Cell Science. So, I got a decent publication, and some decent conference publications early on, and communication awards. I sort of got the ball rolling really quickly just out of pure luck. I never really felt a pressure to publish because I didn't see myself ever as being a PI. I already knew then - I mean the job world has gotten even tougher and even 10 years ago when I finished $\mathrm{my} \mathrm{PhD}$ the job market was really really really tough. I watched some of the postdocs in our lab and I was like, I don't want to be 45 and still doing a postdoc for a real job. I'm probably too ambitious to become a PI because there was too much of a delay - of a lag - and so the publishing pressure was more my pride. I just wanted to share the information and get it out there.

How do you think the public opinion of science has evolved over your career, and do you think that we as scientists have a responsibility to guide the conversation, whether it's our field or with respect to climate change or public health?

There are two sides to that. I think obviously with the Covid pandemic the reception of science information is that in a lot of ways, people are more willing. We hear about the Covid hoaxers and anti-vaxxers and those are 
really, really a small minority. The vast majority of people out there have learned a lot about how science is done, have accepted that early on we didn't think it was airborne and that's why masks weren't required and now they are, and I think most people understand that in an emerging pandemic the science is catching up. I think that in a lot of ways the public trust in science has gone up. But again, we don't hear about those people. We only hear about the squeaky wheels and the people who are going to be antiscience no matter what. The people who aren't getting vaccines are also the climate change deniers, and there's a lot of correlation between all those different things. So they're anti-science people - and they're very loud, but they're not the majority. I think that, in general, people are more trusting in science than they were before.

I think the other thing is that throughout my career, scientists have gotten so much better at communicating. I remember early on even I had this attitude that the data should speak for itself, no one needs to speak for the data. That's changed significantly. I get requests all the time to run science communications workshops amongst the Canadian Forestry Services, and all these different organizations that help mentor other scientists. There's an appetite for learning how to communicate science that there hasn't been before. I think scientists do have a duty to speak for the data. I think it's too nuanced for the public to truly understand and, first of all, everything's behind a paywall so you can't get access to the primary literature anyways. I think there's a duty but also a responsibility on the scientists to really be okay with saying, "I don't know", and recognize that members of the public will hate you for it. They'll say, "Well, you're supposed to know everything, you're a scientist". But what makes me a good scientist is admitting that there are things I don't know, and that I can't speak on. And I think that's really fair. Again, we're not trying to appeal to the people who will never believe anything that comes out of my mouth. I can't care about them. I can care about the other 90 or $80 \%$ of the population who want to trust a scientist. Maybe they don't

\section{"What makes me a good scientist is admitting that there are things I don't know."}

know how or why, but they want to trust that what the science is doing is real.

You mentioned that you got some communication awards at conferences early on - did that sow the seeds for you to then dive headfirst into this science communication realm? It seems like you have a lot of fingers in pies.

I do, yeah, I'm all over the place. You know, I think it was partly my first major international conference. I won a poster award, largely because of pure luck because the stuff I was interested in, unbeknownst to me, was really hot in the worm field with this embryo polarity stuff. So I kind of landed perfectly where everyone was curious about my work, and I do like talking. So it was suitable. I didn't really get it at the time. I was like, Oh, yeah, I got a poster award, I got a free book that Inever read. But then people were like, "You got a poster award at the International Worm Meeting?” And I'm like, "Yeah, first year”, and they're like, “That's a big deal”.

\section{"I think that, in general, people are more trusting in science than they were before.”}

But it was really teaching - being a TA - that made me realize that Iliked sharing science as much as I liked doing science. I did like doing science, but I like talking about science more. I loved to TA, and I realized that that communication side is valuable. When I was finishing grad school, I realized that if you go on to do a postdoc there's almost no teaching, it's just pure research and a lot of admin. I'm really bad at admin, like I hate it with a passion. I just hate meetings, every fabric of me hates anything to do with admin. Ilooked at PIs a lot and it's just sitting through boring meetings. A lot of it is just managing personalities, I don't want any of that.

What do I like to do? I like to teach. I like to talk about science. I like to talk about my work, fine, but it is really boring. I also remember late grad school wishing I had the opportunity to learn more about other fields of science. I was getting really really narrow. My TAships were narrow. Iasked to do a French course or a History of Science course and my committee was like, "You can't take any more extra courses". I wanted to still keep learning, and doing more, but I wasn't allowed so I had to figure out a way to be motivated to learn about other subjects and science in my 
own free time and that kind of started this science communications concept.

What actually started this transition into science communications was when I volunteered as a WISEST Grade 6 team leader for their conference. It's super fun, you just extract DNA out of bananas with these Grade 6 girls. My colleague and I were "Say yes to opportunities that come along." both doing a $\mathrm{PhD}$ at the same time and she just goes, "You're so good at just talking about science, you remind me of Jay Ingram from The Daily Planet”. It was just a throwaway nice compliment, she's a wonderful person who gives all these compliments. But it just happens to be - all this luck - that Jay Ingram was giving a public lecture at the U of A a week later. So Kathy had said, "You'd be good on the Daily Planet with Jay Ingram”, and I was like, Huh, probably would be, then this poster shows up in Biosci that he's giving a talk. So I went to the talk, and then I waited around and met him after and I was telling a little about me and stuff and he's like, "You should join my science communications immersive workshop in Banff this summer, I think you'd be a really good fit". So I did that for two weeks and that's kind of all she wrote.

Do you have any advice for undergrad students who are stuck on this traditional academic pursuit and maybe haven't considered a path like yours?

I would say, say yes. Say yes to opportunities that come along. You never know what they're going to be, whether that's presenting at a WISEST conference and you're nervous to do it, or presenting in the undergraduate conference with a poster, and you say, Well I don't really have any data - present a project poster. Do it, get yourself out there and just say yes to those opportunities that arise. Take courses that aren't part of your degree but you just really want to. Take five years to do your degree if that means you get to take courses that you love.

It's a little overwhelming when you talk to undergrads and they ask, "What do I do? There are so many choices". You're going to have to accidentally find it, to stumble into this opportunity and you'll take some weird class and the prof will be really cool and you'll ask if they taught something else, and whatever the path is, it's not linear.

Right! You might really love ethnobotany, do you even know what that is? No, you won't, till you take it. I've always thrived in uncertainty. I think most people don't, but I don't mind a little chaos. I think high achieving science students really want certainty and they really want to know what to do, and it's really stressful if they don't. I totally understand that mentality, but at the same time don't let that paralyze you into not trying new things and finding what you might want to do.

It's hard to already know what you're going to be passionate about for the next 50 years of your life when you're an undergrad, that's not fair. There's a huge pressure that students feel, that they have to know what they want to do and if it's not medicine, then what are you doing in science? There's this ridiculous notion that everyone in science wants to become a doctor, particularly in my field of biology. Admitting that you don't want to do that, and you also don't know what you want to do, but you just are open to the opportunities that present themselves, is probably the biggest thing. The University has so many things to offer, and so many random courses. Maybe take biomedical engineering, maybe take basket weaving. I don't know. Just take them, right? And just say yes to those opportunities. Go to that intramural game and you never know what's gonna come out. I think so many people are obviously scared to take advantage of these opportunities, to put themselves out there. I get that. But academically, say yes. Just go for it. 